\title{
External Debt Management in Low-Income Countries
}

\author{
Sheku Bangura, Damoni Kitabire, and \\ Robert Powell
}




\title{
IMF Working Paper
}

Policy Development and Review Department

\section{External Debt Management in Low-Income Countries}

\author{
Prepared by Sheku Bangura, ${ }^{1}$ Damoni Kitabire, and Robert Powell ${ }^{1}$ \\ Authorized for distribution by Doris C. Ross
}

December 2000

\begin{abstract}
The views expressed in this Working Paper are those of the author(s) and do not necessarily represent those of the IMF or IMF policy. Working Papers describe research in progress by the author(s) and are published to elicit comments and to further debate.
\end{abstract}

Improving debt management capacity in Heavily Indebted Poor Countries (HIPCs) is a key element of the international community's strategy for ensuring a robust and sustained exit from unsustainable debt burdens. External debt management is a multi-facetted task involving the formulation of a transparent strategy for managing the level of debt, and establishing an appropriate institutional framework that supports effective implementation. This paper brings together the essential elements of effective debt management practices to guide for those assessing debt management capacity and advising on its improvement in low-income countries.

JEL Classification Numbers: H63

Keywords: external debt management; HIPCs; low-income countries

Authors' E-Mail Address: dkitabire@imf.org; rpowell@imf.org

\footnotetext{
${ }^{1}$ Mr. Bangura was a summer intern in the Official Financing Operations Division of the IMF's Policy Development and Review Department (PDR) in 1999. Both Messrs. Powell and Kitabire were in PDR at the time of writing. We would like to thank colleagues in PDR, Monetary and Exchange Affairs Department (MAE), Statistics Department (STA), and in the World Bank for their helpful comments on this paper. Errors and omissions are our responsibility.
} 


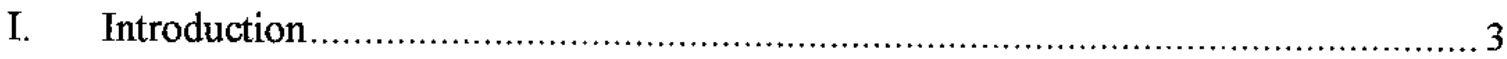

II. Overview of External Debt Management ................................................... 3

III. Essential Arrangements for Effective Debt Management ................................. 4

IV. Essential Elements of Effective Debt Management ...................................... 7

A. Strategy for Managing the Level of External Debt and its Composition ........ 8

B. Monitoring and Maintaining Information on External Debt ..................... 11

V. Computerized Tools, Staff and Training for Debt Recording and Analysis .......... 16

A. Computerized Tools for Debt Recording and Analysis ............................. 16

B. Staff and Training Requirements ................................................. 19

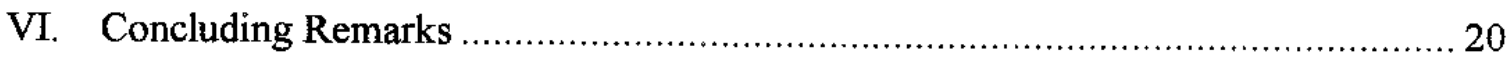

Figures

1. Institutional Framework for Debt Management ............................................ 7

2. Institutional Structure for Debt Management in Uganda ................................... 23

Text Table

1. Computerized Debt Management Systems in HIPCs.................................... 17

Appendices

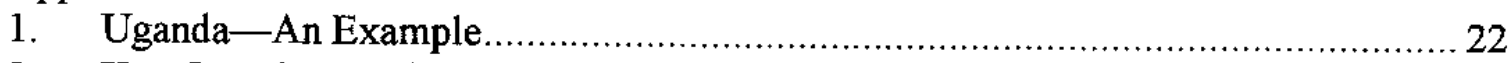

2. Key Questions and Checklist for Assessing External Debt Management in HIPCs........................................................................... 25

3. Project Cycle for Setting up a Computer-Based Debt Management System ......... 32

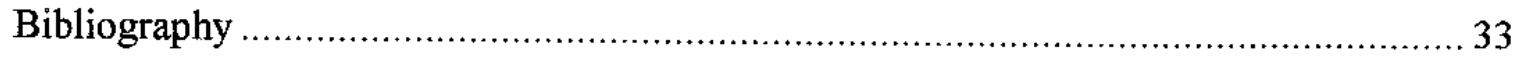




\section{INTRODUCTION}

The primary aim of the Debt Initiative for Heavily Indebted Poor Countries (HIPC Initiative) ${ }^{1}$ is to deal in a comprehensive manner with the overall external debt burden of eligible countries and to reduce it to sustainable levels within a reasonable period of time, provided the countries adopt and pursue strong programs of adjustment and policy reforms. The Initiative builds on instruments already available to the international community to deal decisively with the external debt problems of low-income countries and allows them to exit from repeated debt reschedulings. Therefore, for effective implementation of the HIPC Initiative, a sound external debt management system should be in place. In this context, the IMF and the World Bank have placed increased stress on strengthening the external debt management capacity of HIPCs, and Low-Income Countries (LICs) more generally.

This paper discusses the principal elements of an effective debt management strategy, with a focus on the needs of LICs. It highlights the issues and activities that should be considered in formulating borrowing policies and monitoring loan use and debt service by the public sector. These issues and activities are discussed in the context of integrating debt management with macroeconomic management, both from the institutional and policy perspectives.

The plan of the paper is as follows: Section II provides an overview of external debt management and the objectives of debt management policies and institutions. Section III describes the institutional arrangements necessary for effective external debt management. Section IV describes the essential elements of effective debt management practices. Section V discusses the computerized tools required to enhance the institutional capacity for recording information and evolving external debt management strategies. Concluding remarks are given in Section VI.

\section{OVERVIEW Of EXTERNal Debt Management}

Developing countries use external borrowing as a mechanism to address the gap between domestic savings and desired investment and the export-import gap. ${ }^{2}$ Such borrowing adds to

\footnotetext{
${ }^{1}$ For description of the enhanced HIPC Initiative, see D. Andrews, A. Boote, S. Rizavi, and $\mathrm{S}$. Singh, Debt Relief for Low-Income Countries-The enhanced HIPC Initiative, IMF Pamphlet Series No. 51, 1999, Washington DC, and information on the IMF website (www.imf.org). For an overview of debt relief to LICs more generally going beyond the HIPC Initiative see Daseking and Powell, "From Toronto Terms to the HIPC Initiative: A Brief History of Debt Relief for Low-Income Countries" IMF WP/99/142.

${ }^{2}$ See Chenery and Strout (1966), Two Gap Model in "Foreign Assistance and Economic Development", American Economic Review 56, September 1966, pp. 680-90.
} 
the total resources available to an economy over a given period and enables higher expenditure than would otherwise be possible. If properly applied, the resources can benefit a low-income country and contribute to its economic growth and poverty reduction, and smooth out consumption in response to shocks. ${ }^{3}$ However, when inefficiently allocated, the cost of borrowed external resources can contribute to macroeconomic management problems in the form of high or even unsustainable levels of external debt-servicing obligations. ${ }^{4}$ Before entering into new commitments for external inflows, country authorities should plan and identify all obligations related to such external borrowings and how to repay them, and consider the constraints such debt would impose on future economic policy. The use of borrowed external funds should contribute not only to increased supply of goods to meet domestic needs, but generate-by increasing the country's capacity to export-adequate real resources to service the liabilities incurred. External debt management is, thus, an integral part of macroeconomic management involving the planned acquisition, deployment, servicing and retirement of external loans to foster economic growth, poverty reduction and sustainable development without creating external payment difficulties.

In practice, debt management involves coordinating several major aspects of economic decision making that have a bearing on loan contracting, utilization and the debt servicing needs and capabilities. These key aspects, especially when considered in the context of the institutional structure needed for an effective debt management, are explored in the next section. ${ }^{5}$

\section{ESSENTIAL ARRANGEMENTS FOR EFFECTIVE DEBT MANAGEMENT}

The principal agencies typically involved in managing external debt in LICs are the ministry of finance, the central bank, ministry of planning and/or development, and the central government's treasury or accounting department. In the parastatal sector, responsibility for debt management typically rests with each public enterprise, although line ministries (e.g., agriculture, energy, public works, etc.) and the ministry of finance usually exercise control when a government guarantee is needed. In most countries, public enterprises require a central government guarantee to be able to borrow externally. Very often it is lack of

\footnotetext{
${ }^{3}$ See Avramovic, D. (1964), "Economic Growth and External Debt", Johns Hopkins University Press, Baltimore.
}

${ }^{4}$ See IMF WP/98/72, External Debt Histories of Ten Low-Income Developing Countries: Lessons from Their Experience, May 1998.

${ }^{5}$ For a discussion on the government's financing needs and how its payments obligations should be met at the lowest possible cost over the medium to long run, consistent with a prudent degree of risk, see "Draft Guidelines for Public Debt Management," August 2000, prepared by the staffs of the IMF and the World Bank. 
coordination and cooperation among these principal agencies that results in inappropriate levels and terms of borrowings or incomplete records of a country's debt stock, and difficulties in meeting debt service obligations in a regular and timely manner. For example, various arms of government may sign loan contracts without prior knowledge or authorization of the agency responsible for the finances of the country. Further still, there may be no reference to an external borrowing plan or policy, if such a policy exists. Such uncoordinated borrowing not only complicates debt management, and in particular debt monitoring, but is also a source of wider problems for macroeconomic management.

An effective debt management system should be grounded in a clear legal framework. It would be desirable that there be a clearly laid out institutional arrangements, firmly integrated into the overall framework for financial management of the country. These arrangements should facilitate maximum coordination and cooperation; ensure minimum duplication of activities and sufficient flow of information among the different agencies involved in all aspects of financial management and in debt management in particular. Ideally, these arrangements should be established by legislation, assigning clear responsibility for debt management functions and decision-making to the various state agencies involved. The law should clearly state as to who is able to contract new borrowing on behalf of the state, and for what purpose. Ideally, this responsibility should fall within the ambit of the Minister of Finance. Also, a transparent process would involve parliament, to agree on the terms and the purpose of the borrowing.

The institutional arrangements for debt management necessarily differ from country to country, but their activities should revolve around (i) formulation of debt management policies and strategies, (ii) providing macroeconomic projections and analysis to support policy making, and (iii) undertaking operations to implement terms of loan agreements and maintaining loan records (i.e., monitoring and maintaining information on disbursements and debt service payments). The main institutional priorities for external debt management should be centered on establishing units and working groups with clearly defined mandates and resources for handling these three main tasks in a coordinated manner. ${ }^{6}$

In the area of borrowing policy formulation and planning, a high-level policy coordinating body (PCB) should be in place to coordinate the activities of different government organizations dealing with external borrowings. ${ }^{7}$ It should include top officials from the ministry of finance and the central bank, and may also include sectoral ministries and

\footnotetext{
${ }^{6}$ These arrangements are largely covered in Thomas Klein (1994), External Debt Management: An Introduction pp. 151-157; Lars Kalderen (1992), Institutional aspects of external debt management, in Managing External Debt in developing Countries: Proceedings of a Joint Seminar, Jeddah edited by Thomas M. Klein pp. 87-97.

${ }^{7}$ See UNDP (1997), A report on the joint programme of Debt Management, Discussion Paper 4.
} 
parastatals, which borrow with government guarantees. The chairmanship of this inter-agency body should ideally rest in the ministry of finance because it has ultimate authority for the country's financial stability. This body should formulate annual and medium-term borrowing plans and indicates broad parameters for the type of borrowing necessary to control the level of indebtedness and repayment profile. It should provide general criteria for approval and management of debt in light of the macroeconomic performance of the economy. While this body draws on the specialized knowledge of other agencies to help in establishing external debt management policy, as mentioned above, it should ensure that the legal authority for borrowing or guaranteeing loans in the name of the central government are entrusted in a single agency, preferably, the ministry of finance. This committee could also be responsible for negotiations on existing debt (which require high-level technical skills) with Paris Club creditors, non-Paris Club official bilateral, multilateral and commercial creditors covering rescheduling, cancellations and debt conversions.

In formulating borrowing policies and decisions, projections of future macroeconomic performance are required. Essentially, the fiscal authorities should prepare the projections of future performances. These provide medium- and long-term forecasts of the macro-economic framework including a balance of payments and fiscal operations and undertake analysis to support the decision making process. In making projections, the fiscal authorities would comprise ministry of finance official and should draw on officials from the central bank, and the ministry of economic planning and development where they exist. These should work closely with the debt unit (where it exists it is typically a department in the Ministry of Finance or the Central Bank responsible for debt matters) to obtain reliable forecasts of external debt service and disbursements when making projections of macroeconomic performance.

The maintenance and analysis of statistics on all government and government-guaranteed external debt should be centralized in the debt unit. This unit should have the responsibility to register all loan agreements, collect information on external debt transactions and prepare comprehensive reports on the overall external debt situation on a regular basis. This unit also should have the responsibility to carry out analysis of the loan portfolio and to provide support for policy formulation and guidelines on new borrowing terms. The debt unit should serve as the primary source of information for the policymaking committee and its analytical support committees. It is recommended that the debt unit would be located in the agency charged with the authority to approve all borrowings (public and publicly guaranteed), which stands as the official point of contact between individual creditors and the central government. The choice is often between the ministry of finance and the central bank. Independent of the location of the debt unit, a sufficient flow of information to facilitate the setting up of a complete database on external debt is important.

Working groups consisting of representatives from each of the agencies with substantial involvement in loan operations need to be formed to ensure the flow of information to the debt unit. These groups should include officials in project implementing agencies who handle disbursements, central government accounting department officials who process debt service 
payments- and disbursement-related issues, central bank officials who handle debt servicing issues, and ministry of finance officials responsible for monitoring the budget.

An effective framework for arranging debt management institutions is illustrated in the pyramid below.

Figure 1. Institutional Framework for Debt Management

Decision-making

Macroeconomic projections and analysis

Implementation/monitoring loans and maintaining loan information

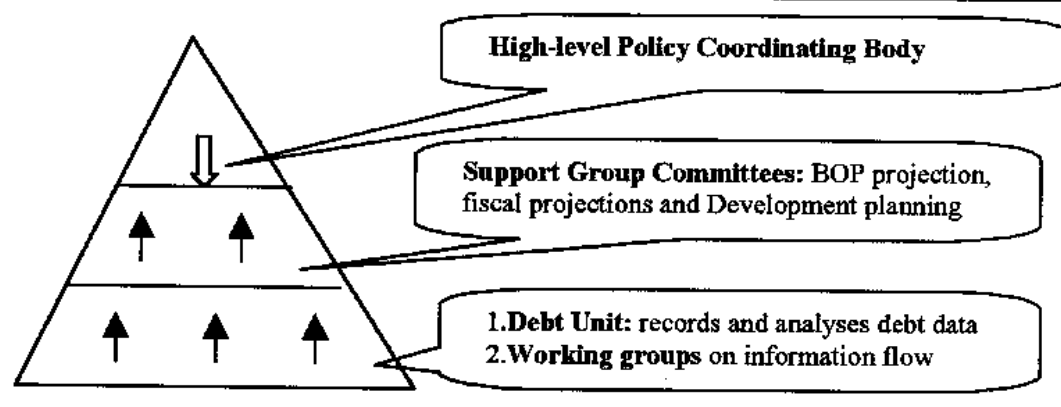

IV. ESSENTIAL ELEMENTS OF EFFECTIVE DEBT MANAGEMENT

Key elements of an effective external debt management should include the following:

(a) Policy guidelines on the appropriate level, terms and purpose for foreign borrowing;

(b) Reorganization of the existing stock of debt so as to maintain an optimum debt structure;

(c) Monitoring the operations relating to loan commitments, disbursements (loan utilization) and debt servicing on all borrowings preferably on a loan-by-loan basis;

(d) Accurately recording and maintaining detailed loan-by-loan information in a computerized database;

(e) Preparing projections of debt and debt service levels to facilitate domestic cost budgeting and foreign exchange management;

(f) Liaison with various creditors, keeping them informed of macroeconomic developments and of the authorities' policy intentions;

(g) Clear policy guidelines on project selection for inclusion in a public investment plan. Projects should meet the technical/economic evaluation standards, but should also meet 
the country's policy guidelines. In most LICs, this should include poverty reduction priorities;

(h) Regular portfolio reviews on a sector and/or creditor basis. In a portfolio review it should be possible to cancel projects, which are not performing well, and stop new loan disbursement; thus containing future debt servicing costs.

These elements can be divided in two broad categories: (a) formulating a strategy for managing the level of debt and its composition, and (b) undertaking measures to ensure adherence to the obligations associated with contracted external loans. The issues and activities that must be covered under these elements are discussed below with a focus on integrating debt management with the overall macroeconomic management.

\section{A. Strategy for Managing the Level of External Debt and its Composition}

External borrowing is inherently a dynamic activity. While it increases resources available in the disbursement period, it has long-term repercussions associated with the call on future productive resources to service it. The growth of external debt should, therefore, be planned. The level of new external borrowing and the terms on which it may be contracted should be clearly established and made public. The primary rationale for establishing conditions or limits on the extent of new external borrowing, which are customary under IMF arrangements, are to ensure the overall consistency of economic management. They also serve to prevent an undue build-up of external debt leading to debt-servicing problems in the medium term.

The assessment of borrowing requirements is a basic macroeconomic policy issue involving projections of economic activities covered in the balance of payments and government fiscal operations. These projections have to reflect the most likely outcome of domestic conditions as well as assumptions concerning the external environment to ensure realistic projections of the appropriate financing requirements. Since by definition HIPCs already have a high external debt burden and are often particularly vulnerable to external macroeconomic shocks, they need to exercise particular caution in establishing borrowing levels. In the past, overly optimistic projections of economic activity and the external environment have been a factor in leading to excessive borrowing in many LICs. ${ }^{8}$ Assumptions should, therefore, be made cautiously and prudently. As new borrowing levels should be established within the framework of countries' capacity to service debt in the future, forward-looking analysis of the country's external debt-servicing capacity should be an integral component of the external debt management process.

\footnotetext{
${ }^{8}$ In IMF WP/98/72, optimistic export-growth projections were identified as contributing factor to the debt accumulation in low-income countries. This factor is supported in "Sources of Debt Accumulation in a Small Open Economy", IMF WP/97/146, which shows that an optimistic view of policy makers is compatible with rational behavior and can generate persistent overborrowing.
} 
This involves analysis of the existing stock of external debt and the streams of future debt service obligations in relation to the country's economic performance, taking into account its GDP growth, export growth, import requirements and the level of reserves in the medium term. The objective of such analysis is to ensure that external borrowings are undertaken only within sustainable levels. Each country should establish its own guidelines on what it considers to be prudent borrowing levels, or excessive or unsustainable debt. In practice, the level of sustainable debt in each country will also depend on the expected level and form of future financing flows, including aid flows. The thresholds established by the international community in the context of the HIPC Initiative could serve as guideposts for acceptable levels of debt in LICs. Debt indicators should preferably be kept below these levels, and borrowing that would cause debt indicators to rise above these levels should be avoided.

The standard approach in undertaking this assessment is to have a simple model that helps in projecting balance of payments flows, debt-servicing requirements and generating the indicators that provide warning signals of impending debt-servicing problems. This should allow the calculation of the most common debt indicators: the debt-service ratio, the present value of debt outstanding to exports of goods and services, external debt to GDP ratio, the reserves to import ratio (reserve coverage), and reserves to short-term debt ratio. Having established the underlying macroeconomic assumptions and calculating the relevant mediumterm balance of payments and budget projections which establish the projected financing requirements, the other key issue to be considered is how these requirements can be filledby grants, concessional loans or commercial borrowing. Although some LICs have access to commercial borrowing such as export credits or loans from commercial banks, for most LICs, the goal is to reduce non-concessional loans ${ }^{9}$ to a minimum, obtain the most concessional terms possible, and maximize grant receipts from donors. In the context of borrowing limits under Fund arrangements, a minimum grant element of 35 percent is typically required for a loan to be considered concessional. ${ }^{10}$ For Least Developed Countries (LDCs), the OECD consensus on export credits requires a 50 percent concessionality level.

A loan portfolio review should be undertaken regularly, analyzing the existing debt stock with respect to the currency composition, the maturity profile and the interest rate structure in order to support the establishment of guidelines on the appropriate level and terms of new borrowing. The analysis of the interest rate structure should focus on the optimal balance between floating and fixed interest rates loans in the portfolio. It should also seek to identify the major base rates (e.g., U.S. prime rate, LIBOR) applicable to the loan portfolio and identify any form of over-exposure to any single base interest rate. The currency composition of the loan portfolio, as much as possible should avoid undue foreign currency risk taking

\footnotetext{
${ }^{9}$ Grant element is a composite indicator that takes into account the maturity, grace period and interest rate of the loan. It is calculated as the present value of the future stream of debt service payments as percentage of the face value of the loan.

${ }^{10}$ Using market interest rates (CIRRs) as discount rates.
} 
into account the currency composition of foreign earnings and of reserves to identify any form of foreign exchange exposure. Financial derivatives could be considered as an efficient way of hedging risk e.g. if export earnings were in one type of currency but because of market conditions, the country borrows in another currency, derivative contracts could help match the foreign currency cashflows.

The remaining maturities of loans in the portfolio should be analyzed regularly to identify any bunching of payments due. A portfolio review could also include review of projects, assessing their performance over the years of implementation. Low performing and nonperforming projects could be cancelled, stopping disbursements and thus saving on future debt servicing.

In many LICs, financing of inefficient public investments and lack of sustained implementation of sound macroeconomic and structural policies to support investment and export growth have in the past contributed to the build-up of unsustainable external debt. These failures provide important lessons and guidelines for planning the future use of borrowed funds. The choice of appropriate projects and programs to which borrowed resources are channeled is important in articulating borrowing decisions especially in HIPCs A Public Investment Program (PIP) could be enunciated to support the choice of appropriate projects, which require external financing. This program should form the basis for appraising and prioritizing desired investment projects, which need to meet certain criteria. The PIP should be consistent with the Government's stated policy of resource allocation and terms of borrowing and projections for debt burden indicators. Several factors should be taken into account when making borrowing decisions, among are: ${ }^{11}$

(i) Projects to be financed by the borrowed funds should be in line with the sectoral strategies and national priorities, which, ideally should be articulated in the Public Investment Plan (PIP).

(ii) The efficiency of resource use relating the benefit of inflows to the cost of borrowing, that is, whether the economic rate of returns on investment programs are expected to exceed the rate of interest payable;

(iii) The growth of output and exports as they relate to the cost of borrowing in real terms.

While an appropriate project choice is crucial in contracting new loans, the policy environment needed to support appropriate investment decisions should not be unduly distorted by inappropriate economic policies. A project that appears to have high returns in

11 These criteria are discussed in the World Bank publications and elsewhere. For example, by Armin Gutowski and Manfred Holthus (1986) on "Limits to International Indebtedness" in "Indebtedness and Growth in Developing Countries" edited by A. Gutowski, M. Holthus and D. Kebshull, Hamburg, 1986. 
the planning stage when distortions exist may prove not to be so in the absence of distortions. Overvalued exchange rates, tariffs that protect inefficient industries and inappropriate administered prices are examples of such distortions. The elimination of such distortions is important for the successful utilization of borrowed funds.

Debt reorganization may take different forms. It may be debt rescheduling in which payments of principal and/or interest due during a specified period (known as the consolidation period) are restructured with a new repayment schedule and terms. It can also take the form of refinancing, which is new borrowing primarily aiming to meet specific payment obligations on existing debt. Refinancing options are not typical in LICs because of their limited market access. Eventually, however, LICs need to manage their external debt in a way that strengthens their relations with all creditors and enhances their use of other tools of external debt management. Within the framework of effective debt management, rescheduling of debt should be considered only as a temporary and exceptional measure occasioned by temporary constraints faced by countries in meeting debt-servicing obligations. Partly related to the fact that rescheduling of debt to bilateral creditors in the Paris Club has involved an increasing element of debt reduction, rescheduling has become a regular element of the debt management strategy in many LICs, and has been used as a regular means to assist in filling external financing requirement. Notwithstanding the immediate foreign exchange cash flow relief provided by rescheduling, an effective debt management strategy cannot be based on continuous rescheduling. The aim should be for a country to exit from the rescheduling process and restore regular relations with all creditors. This objective has been a key focus under the HIPC Initiative.

\section{B. Monitoring and Maintaining Information on External Debt}

The previous section covers the issues and activities involved in the formulation of strategies for contracting external debt. In addition, the loan agreements have to be implemented.

Disbursements of funds and servicing of external debt obligations have to be monitored. This involves step-by-step follow-up of operations in the loan cycle, covering detailed transactionby-transaction information on loan commitments, disbursements and debt-service obligations. From the debtor perspective, external debt can be broadly classified as public, publicly guaranteed, and private sector debt. The external debt may be long term, medium term, or short term. Also, public sector and publicly guaranteed external debt can be further disaggregated into the following categories:

(1) Central government direct debt, that is, borrowing undertaken by the central government or a local government, which is serviced from the budget of the central government;

(2) Central government-guaranteed debt, that is, borrowing undertaken by a private or public enterprises or local governments, that is guaranteed by the central government. The local governments and public enterprises service their debt obligations, but these obligations may be a contingent liability of the central government budget in the case of default; 
(3) Unguaranteed public enterprise direct debt, that is, borrowing undertaken directly by public enterprises, serviced by public enterprises and not guaranteed by the central government. It could also include direct borrowing by a local government and not guaranteed by the central government. However, in case the local government or public enterprise defaults, the contingent liability may fall on the central government, depending on the legal provision covering external borrowing of the country concerned.

Under the HIPC Initiative, external debt coverage is limited to public and publiclyguaranteed external debt, including all medium- and long-term borrowing of the central government, central bank and parastatals from multilateral institutions, bilateral governments and commercial creditors whether or not the government directly guaranteed them. Private sector borrowings not guaranteed by government are also important for debt management as they may make a country vulnerable to a financial crisis.

The central government has direct responsibility for managing two types of debt obligations: (1) direct debt for which the government is solely liable, and (2) guaranteed debt for which it has a contingent liability if the primary borrower defaults. The central government, therefore, has to have full knowledge of such guaranteed borrowings. A comprehensive inventory of all loan agreements with detailed information on each loan needs to be compiled and centrally maintained in the debt unit, specifically set up for monitoring and maintaining debt information. Basic loan details required are generally available from the original loan agreements. They should include:

- The type of instrument, the creditor institution, country (for bilateral creditors), e.g., loan (bilateral, multilateral, commercial bank); suppliers' credit; and other loans.

- The debtor, that is, whether the funds are for the central or local government or state enterprise and whether it is guaranteed by the central government or not;

- The amount committed and currency of the loan, commitment fees, rate of interest, grace period, repayment period, number of installments per year and special features such as options;

- The agreement date, the date from which commitment fees accrue, date of effectiveness, events of default and the terminal date for disbursements;

- $\quad$ Also, the purpose for which funds have been borrowed and prior conditions for the loan to be effective or drawn down.

Agreements on all central government borrowing should be available in the ministry of finance or the agency designated for authorizing foreign borrowing as the case may be. In the case of central government guaranteed debt, the debt unit should get copies of loan agreements immediately after signature. In many LICs this has not been the case in the past. Recently, as the requirements of the HIPC Initiative have forced a more complete 
reconciliation of debtor and creditor data, many HIPCs have had to contact creditors to assist in building such a comprehensive debt inventory. To allow a continuous updating of the loan inventory, procedures should be in place for the debt unit to obtain all loan contracts from borrowing agencies, and maintain contact with loan negotiations to keep abreast of pending new borrowing.

After a loan agreement has been concluded, steps should be taken by all concerned agencies to fulfill the conditions necessary for effectiveness of the loan. After a loan becomes effective, contracts have to be concluded for the supply of machinery, equipment and services, etc., and for the cash transfers under the agreement. The next step is monitoring loan disbursements in a systematic and orderly manner, updating the loan status and information, and reviewing the progress of loan utilization at regular intervals.

The debt unit is unlikely to be directly involved in the process of loan utilization. This is usually handled by project executing agencies, the central bank or the commercial banks designated for operating project accounts, and the central government accounting or budget division. However, the debt unit should maintain information on disbursements (both forecast and actual) to able to advise on the management of the budget, the balance of payments and the public investment plan implementation.

It is often the case in LICs that funds allocated under loan agreements may not be used on the schedule specified in the loan agreement because of weaknesses in project administration and delays involved in fulfillment of the conditions of loan disbursements. Delays can result in a build-up of commitment charges, and have implications for both budgetary and balance of payments management. There should be a system of following up on loan disbursements. The pace of loan disbursements should be reviewed from time to time and compared with estimates in the budget and necessary actions taken to expedite loan utilization. The data required on disbursements (actual and forecast) should include:

- Amount and currency of disbursement, and undisbursed balance;

- The method of disbursement, that is, whether it is by direct payment to suppliers, on a reimbursement basis, or by other means such as advances;

- A disbursement schedule.

The procedures for disbursements vary, depending on whether it is a loan for balance of payments support, a project loan or export credits. Disbursement notices may be sent by creditors for each disbursement or at periodic intervals covering disbursements on a single loan or a group of loans. These statements are often a good source of information, though in some instances difficulties may arise when creditors do not identify disbursements on different loans separately. On the other hand, if disbursements are made on a reimbursement basis, the central bank or commercial banks maintaining project accounts could report disbursement information to the debt office each time remittances are received. In cases 
where disbursements do not lead to the inflow of foreign exchange but instead to physical imports following direct payments to suppliers by the creditor, disbursement notices from creditors would remain the main source of information for the debt unit of the debtor government. As these notices may not always be readily available, the debt unit may need to follow up with the implementing agencies and/or with the creditors. The cooperation of both creditors and implementing agencies is, therefore, essential to ensure efficient procedures for collecting disbursement information.

Noting that various methods of disbursements exist and therefore the varying sources of capturing disbursement information, the challenge for the borrowing government is to ensure that its figures on disbursements are consistent with those reflected in government expenditure records and in the balance of payments accounts. An important task of the debtor government is to ensure that debt-service payments are made on schedule, in the form required by individual creditors and that accurate records of such payments are maintained. This task has implications both for the fiscal budget and the management of foreign exchange reserves. Thus a forecast of the complete schedules of annual debt-service obligations to all external creditors should be prepared to facilitate budgetary and foreign reserve programming in the ministry of finance and the central bank.

For central government debt, servicing typically involves three main agencies-the debt unit, the central government accounting department (normally in the ministry of finance), and the central bank. Payment instructions for monthly debt service typically emanate from the debt unit, which at the beginning of any fiscal year should ensure that budgetary and foreign exchange provisions have been made for the obligations coming due. These instructions should be crosschecked against invoices or billing statements for debt service from creditors. Payment instructions have to spell out to the central government accounting department, the foreign currency and its local currency equivalent of payments due, the account particulars of the creditors, and the due date of payments. The accounting department typically transmits local currency payments to the central bank and requests for equivalent foreign currency remittances to be paid to the creditor's account abroad. This process can be swift or protracted, depending on the level of collaboration between these agencies. In cases where this process results in significant delays, it may be useful for the central bank to have blanket authority within the budgetary limits for direct debt servicing, and a periodic reconciliation of accounts with the government's accounting department would be undertaken. This could help minimize penalty charges, but should not compromise accounting and budgetary requirements, or passing the relevant information to the debt unit and/or to the ministry of finance.

In addition to procedures established for ensuring that creditors receive debt-service payments in time, proper records of all principal repayments, interest payments, commitment fees, services fees and other charges should be maintained. These help in minimizing the build-up of arrears or penalty charges in cases of delayed payments. Any changes resulting from modifications of loan agreements such as enhancements or cancellations of the original loan amount, refinancing, rescheduling, prepayment and write-offs should be recorded since these will affect debt-service profiles. The debt unit should pay particular attention to multi- 
currency and variable interest rate loans that are affected by both exchange rate and interest rate adjustments, since these changes may also affect projected debt service.

Information on actual cash debt-service payments for direct central government debt normally is obtained by the debt unit from the central government accounting department and the central bank. Sometimes, due to administrative bottlenecks, it may take time for payments authorized by the debt unit to be effected. In such cases the debt unit may need to follow up payment transactions and reconcile actual debt service with the central bank and the general accounting department on a regular basis.

It is sometimes difficult to obtain information on direct payments by public enterprises for debts guaranteed by the government, and more so, if such enterprises that initially took on the debt have been privatized. While the central government may not have the obligation to budget for these payments, as the guarantor it would have to assume the contingent liability if default occurs; thus the debt unit should monitor and, to the extent it can, ensure that debtservice payments are made on due dates by the primary borrowers. It may be helpful for the debt unit to maintain a calendar of returns to ensure the payments of guaranteed debts on scheduled dates and establish reporting requirements for state enterprise loan obligations, both guaranteed and unguaranteed.

Private non-guaranteed debt is typically not high in most LICs. Where possible it should be monitored because servicing of obligations on private non-guaranteed debt may also have significant macroeconomic implications. Ideally, the level of detail obtained on private nonguaranteed debt need not be the same as for public and publicly guaranteed debt. Data on private non-guaranteed debt is often difficult to obtain since the government is not normally involved in loan negotiations or implementation. The data collection process may be more readily facilitated when a country has an exchange control system in place. ${ }^{12}$ In this case, the central bank may have data on private debt transactions through its exchange control authorities and this can serve the needs of the debt unit.

In the situation where there are no exchange controls, data may have to be obtained either through commercial bank records and/or by a survey of private companies. Surveying banks and private companies for information on external debt requires a range of skills that do not fit naturally with a debt office whose main function is to monitor and compile data on external debt of the public sector. These skills include survey design, and developing a register of enterprises to approach. Also, encouraging the cooperation of enterprises that maybe reluctant to report can be resource intensive. For these reasons, the debt office is encouraged to cooperate with other agencies that are more familiar with dealing with private enterprises.

${ }^{12}$ The authors do not advocate the imposition of exchange control for this purpose. 
Commercial banks are typically required to file periodic balance sheet reports with information on their foreign assets and liabilities. Such reports may be required to separate long-term from short-term assets and liabilities. This may be a major source of information for the debt unit in monitoring outstanding foreign debt of banks. The Central Bank may, therefore, need to include external debt reporting in its reporting requirements from commercial banks. In the case of a survey being undertaken, the private sector would need to be assured that information is used for statistical purposes only. Effective legislation to guarantee the confidentiality of information may help to overcome resistance by private enterprises in responding to questionnaires. Commercial banks and private enterprises would need to cooperate in providing information on transactions to the statistical agency, central bank and/or the debt unit.

The Bank for International Settlement (BIS) and the OECD publish data on external liabilities of private sector entities to international banks. Given the likely paucity of data domestically in LICs, some effort should be made to reconcile information gathered on private sector borrowing to improve the information on private sector exposure. Full reconciliation is rarely possible and in most cases requires very specialized technical assistance.

The above discussion on debt monitoring has concerned long-term debt. Short-term debt (loans with maturity of one year or less) can be volatile and can create major problems for a country's debt management. A particular problem for many LICs is that the build up of short-term may go unobserved until it becomes a problem, at which point the options for dealing with this source of vulnerability may be limited. Instruments involved typically include inter-bank lines, direct suppliers credits, letters of credit, and non-resident deposits in domestic banks. Debt management in LICs should include putting regulations and procedures in place to monitor this category of debt. Central banks are best placed to organize information on short-term debt because - with the exception of suppliers' credits-most of the transactions take place through the banking system.

\section{COMPUTERIZED TOOLS, STAFF AND TRAINING FOR DEBT RECORDING AND ANALYSIS}

\section{A. Computerized Tools for Debt Recording and Analysis}

Most HIPCs maintain computer-aided systems for debt management. The Commonwealth Secretariat-Debt Recording and Management System (CS-DRMS) and the UNCTAD Debt Management and Financial Analysis System (DMFAS) have been the two most commonly used software packages. Countries may reduce both costs and risks by adopting one of the two systems as their core system rather than trying to re-invent their own. A few countries 
use self-designed spreadsheet programs and a number of LICs have projects in the pipeline to establish a computer-based debt recording and management system (Table 1 below). ${ }^{1314}$

Table 1. Computerized Debt Management Systems in HIPCs

\begin{tabular}{lll}
\hline CS-DRMS & DMFAS & Other Systems \\
\hline 1 Benin & 11 Bolivia & 32 Angola \\
2 Cameroon & 12 Burkina Faso* & 33 Congo-Brazzaville \\
3 Gambia & 13 Burundi & 34 Guinea \\
4 Ghana & 14 Central Africa Rep. & 35 Lao People's Dem. Rep. \\
5 Guyana & 15 Chad** $^{*}$ & 36 Liberia \\
6 Kenya & 16 Cote d'Ivoire & 37 Myanmar \\
7 Mali & 17 Ethiopia & 38 Niger \\
8 Nigeria & 18 Guinea-Bissau* & 39 Somalia \\
9 Sierra Leone & 19 Honduras & 40 Congo-Kinshasa \\
10 Tanzania & 20 Madagascar* & 41 Gambia, The \\
& 21 Mauritania & \\
& 22 Nicaragua & \\
& 23 Rwanda & \\
& 24 Sao Tome \& Principe & \\
& 25 Senegal & \\
& 26 Sudan & \\
& 27 Togo & \\
& 28 Uganda & \\
& 29 Vietnam & \\
& 30 Yemen** & \\
& 31 Zambia & \\
& & \\
& &
\end{tabular}

Sources: UNCTAD DMFAS; and World Bank Debtor Reporting System.

Note: * DMFAS installation planned

** DMFAS projects being negotiated

${ }^{13}$ Appendix III describes the project cycle of computer-based debt management systems. Refer to Hunsberger (1987) for detailed explanation. This would form the basis for evaluating progress towards establishing good debt management system in countries that have projects in the pipeline.

${ }^{14}$ Installation of the CS-DRMS in Benin, Cameroon, and Mali was carried out by IDRC (International Development Research Consortium), Canada in collaboration with the Commonwealth Secretariat. 


\section{Main features of the UNCTAD and Commonwealth Secretariat systems}

The following features describe the main functional elements of the two most common computer systems used for debt management purposes in HIPCs.

\section{Loan-by-loan data entry and making projections of future transactions}

Both the CR-DRMS and DMFAS facilitate the setting up of a loan-by-loan database for a country. They generate projections of disbursements and debt service obligations to support budgetary and foreign reserve management.

\section{Produce standard reports}

These systems produce reports on various aspects of a country's loan portfolio. Reports can include single loan summaries and histories, arrears notice, debt outstanding, future debt service, etc.

\section{Analytical and management tools}

Both systems provide support facilities for:

(a) Sensitivity testing to determine the effect of variations in exchange and interest rates on future debt service;

(b) New loan testing to evaluate loan offers or possible borrowing strategies;

(c) The calculation of debt indicators by drawing upon debt data and macroeconomic indicators;

(d) Calculation of grant elements in loans;

(e) Applying the effects of structural changes to the debt portfolio database resulting from refinancing, rescheduling and other reorganization exercises.

\section{Interfacing with other systems}

Both systems interface with other external systems for purposes of:

(a) Importing debt data (e.g., transactions information from an accounting system);

(b) Exporting debt data (e.g., aggregate data to a spread sheet for inclusion in a macroeconomic model);

(c) Reporting debt data in electronic form to external agencies (e.g., World Bank). 
Notwithstanding, the wide availability of both the Commonwealth Secretariat's CS-DRMS and UNCTAD's DMFAS among the HIPCs, largely the focus of the use of these packages has been in the area of recording of debt information. ${ }^{15}$ Less effort has been directed in the past to forward-looking debt analysis. Currently, within the framework of the HIPC Initiative, forward-looking analysis such as Debt Sustainability Analysis is required for assessing countries' eligibility for HIPC Initiative assistance. This analysis is expected to form a major component of debt strategy formulation in countries at various stages of implementing the Initiative and after graduation from the Initiative as part of normal debt management procedures. In conjunction with the CS-DRMS and DMFAS systems, new debt software packages for forward-looking debt analysis have been developed. These include the World Bank's "DSM+"(Enhanced Debt Strategy Module) and "Debt-Pro", a commercial package developed by International Debt Management Inc.

Both DSM+ and Debt-Pro are modeling frameworks that can be used to supplement a comprehensive macroeconomic/balance of payments projection model. They are designed for use on microcomputers to perform broad range of debt analysis and simulations. These packages offer capabilities to carry out Debt Sustainability Analysis within the context of a well defined, medium- or long-term macroeconomic scenarios. They support the calculation of present values of debt using specific discount rates and loan-by-loan data. They support simulations to fill fiscal and external financing requirements as well as produce results for ratios linked to exports, fiscal revenue and GDP. In addition, these packages facilitate the estimation of vulnerability indicators such as export volatility, the current account deficit and reserve coverage under different scenarios. The use of these or similar programs in collaboration with the CS-DRMS and DMFAS enhances the overall effectiveness of debt management.

\section{B. Staff and Training Requirements}

Countries face problems in recruiting and retaining trained personnel for handling external debt management issues. Experience suggests that there is usually a high rate of turnover of external debt management staff, and training would need to be an on-going task. Welltrained, highly motivated staff can go a long way to minimize borrowing costs and help manage loan proceeds in an optimal manner. The saving that a country can make from an effective debt management system operated by trained personnel can more than compensate for the cost of operating a debt unit. While technical assistance can be obtained to undertake debt strategy formulation and analysis, the expertise and capabilities required for good debt management should eventually be developed in-house. In the event that this cannot be done in-house, the Government should consider alternatives like itinerant contractual staff or even permanent external staff. A government should have a technically competent debt

\footnotetext{
${ }^{15}$ See Managing External Debt in Developing Countries: Proceedings of a Joint Seminar, Jeddah, May 1990, World Bank Discussion Paper 155, edited by Thomas Klein 1992 for country experiences with computer-based debt management systems.
} 
management team with a practical knowledge of loan instruments, which keeps abreast of developments taking place in creditor markets (bilateral, multilateral and commercial banks).

The most fundamental training requirements are in the areas of interpretation of loan agreements relevant to the country's loan portfolio; extracting loan particulars from creditor statements of importance to the database; the use of debt software for data recording and producing reports and debt (re)negotiations, payments and disbursements. UNCTAD and the Commonwealth Secretariat provide training in some these areas. Debt Relief International ${ }^{16}$ (DRI) has provided many HIPCs with training on debt management issues and has contributed to the build-up of regional expertise and training facilities. These are very important due to staff turnover in HIPCs and regular training is likely to be required locally.

Training in the use of the computerized systems for debt policy analysis is particularly important for LICs. This should include the capacity to undertake debt data analysis of a country's portfolio covering the key characteristics of its portfolio such as the currency composition, interest rate structure, maturity structure, purpose and key sectors that use borrowed funds. Another important area will be sensitivity analysis on individual loan of changes in interest rates and in exchange rates on debt service.

The HIPC Initiative requires that debt sustainability analysis is done on a regular basis for all HIPCs, in the first place, to determine countries' eligibility for assistance and secondly, to help countries in their future debt management strategy. This requires use of a debt database to generate debt sustainability indicators, simulate Paris Club and other rescheduling options, and alternative ways of filling countries' financing gaps. In this area, Debt Relief International (DRI) runs a capacity building training program supported by a number of bilateral donors.

\section{CONCLUDing Remarks}

External debt management should not be seen in isolation from the general macroeconomic management. External debt management has close links with management of the fiscal budget, foreign reserves and the overall balance of payments. Its effectiveness requires both good policies and strong institutions to regulate and co-ordinate borrowing. These should be set up as part of the overall framework for managing the macro-economy. LIC governments should develop their own clear view on what constitutes an excessive level of debt, and

${ }^{16}$ DRI is a London-based consultancy executing the HIPC Debt Strategy and Analysis Capacity Building Program funded by the governments of Austria, Denmark, Sweden, Switzerland, and the United Kingdom. 
follow borrowing policies that prevent such a build-up in the future. Institutional arrangement should facilitate a sufficient flow of information and enhance the degree of coordination among agencies. 


\section{Uganda-An Example ${ }^{17}$}

Uganda presents an example of a developing country and HIPC with well-developed institutional arrangements for external debt management, integrated into macroeconomic management. After years of policy weaknesses and operational shortcomings on external debt issues, in 1991 the Ugandan government undertook to strengthen the role of external debt management in its overall macroeconomic management. It established a number of committees charged with overseeing and monitoring external debt issues. These included:

(1) The Balance of Payments Committee bringing together officers from the Central Bank and the Ministry of Finance specialized in external debt and trade issues to discuss strategy, consider trends and analyze the sustainability of debt burden.

(2) The Cash Flow Committee providing the forum for discussing debt issues in the context of the whole macroeconomic framework. This enables the Central Bank and the Ministry of Finance officials to consider the fiscal revenue constraints that debt service may have in the short term and their repercussions on other sectors of the economy.

(3) The Development Committee, which consists of senior members of the Ministries of Finance and Planning and representatives of the line ministries, provides an executive forum for high-level coordination and exchange of views, thus enabling policy decisions to be made with valuable input from all institutions. This Committee thus provides the overall coordination necessary for identifying priority projects and their source of financing, approving new projects only when necessary. Once the Development Committee approves projects, they are then included in Public Investment Plan (PIP). In approving projects, the Committee now ensures that these projects address poverty eradication directly or indirectly.

These committees work closely with the External Debt Management Office located in the Central Bank of Uganda, which is charged with the main task of recording, monitoring and analyzing the country's external debt. It serves as a support line for data analysis to the other committees.

The institutional arrangements for managing external debt in Uganda have been adaptive to developments in the country's external debt strategy.

${ }^{17}$ This example draws largely from a paper presented by D. Kitabire on "Uganda's Debt Strategy: An example of the need for flexible, coordinated institutions in a changing macroeconomic environment" at the UNCTAD Debt Management Conference in Geneva, December 1997. 
As part of its debt strategy, the government launched the Multilateral Debt Fund (MDF) in 1995, which pooled donor contributions used to service debt to IDA, the IMF, and the African Development Bank/Fund. The government requested the donors especially those that were contributing to the MDF to form a donor committee. The objective of the committee was to ensure that donor funds were being used in the desired way and also to ensure that government policy shared their overall aim of reducing debt and taking on new loans only for priority projects that met the guidelines of Uganda's Poverty Eradication Action Plan (PEAP) and the loans were on concessional terms with a grant element equivalent to IDA resources or more. As a matter of policy, loans are only accepted if the Government has failed to access grant financing for the project. This committee was expanded to monitor the use of HIPC relief and other donor resources put in the Poverty Action Fund (PAF). The donors, civil society, and the government (both local and central) meet quarterly to discuss recent development on debt and the delivery of services against the budget allocations under the PAF.

Uganda also formed a Debt Sustainability Working Group. It pools external debt officers from the Ministry of Finance and the Central Bank to prepare regular updates of the debt sustainability analysis (DSA) and provides policy makers with advance warning of potential developments, which may exacerbate the debt situation.

\section{Figure 2. Institutional Structure for Debt Management in Uganda}

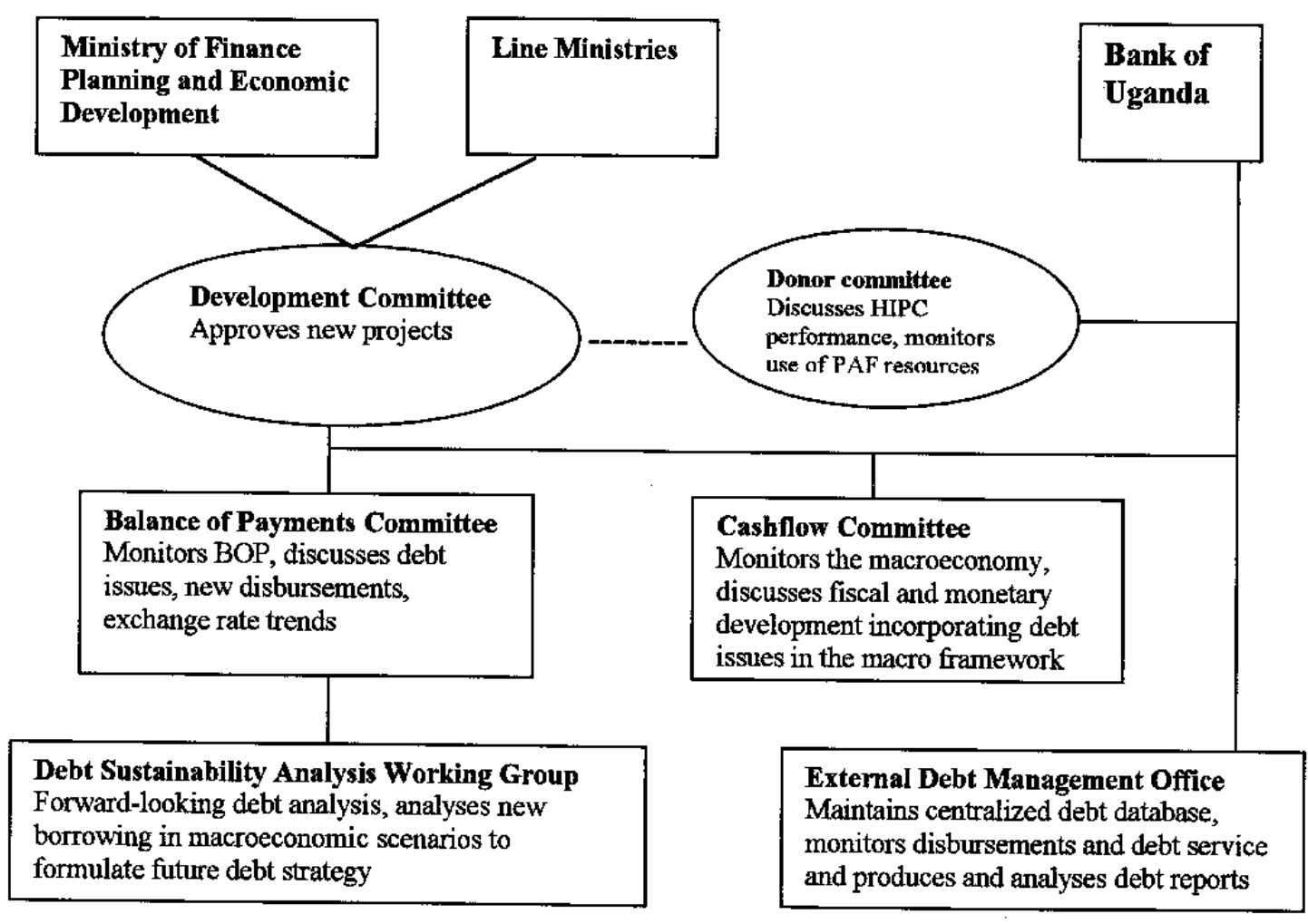




\begin{abstract}
Although each of these committees and agencies serve specialized functions, a good deal of interdependence and cooperation exist between them, as is shown in the figure. The External Debt Management Office receives cooperation and information from the Ministry of Finance, line ministries, the Planning and Development Ministry, and departments in the Central Bank to facilitate data recording. The Debt Management Office in turn provides the necessary debt statistics and analysis to aid the activities of the various committees. The Balance of Payments and Debt Sustainability Analysis Working Groups provide support to the various Committees for the formulation of policies on new borrowings and loan renegotiations. The actual negotiation is usually done by senior management of the Ministry of Finance with technical support from the staff of Ministry of Finance, the Bank of Uganda, and the Ministry of Justice provides legal advice.
\end{abstract}




\section{Key Questions and Check-list for Assessing External Debt Management in HIPCs}

Key questions include the institutional set up for the following tasks and how they are executed in practice:

(a) Planning and providing policy guidelines on the appropriate level and terms for foreign borrowing;

(b) Assisting, where necessary, in the task of reorganizing the existing stock of debt so as to maintain an optimum debt structure;

(c) Monitoring and controlling operations relating to loan commitments, disbursements (loan utilization) and debt servicing on all borrowings on a loan-by-loan basis;

(d) Recording and maintaining accurately detailed loan-by-loan information in a database;

(e) Preparing projections of debt and debt service levels to facilitate domestic cost budgeting and foreign exchange management;

(f) Liaising with various creditor groups, keeping them informed of macroeconomic developments and the authorities policy intentions.

The following checklist covering (a) institutional arrangement and (b) computer tools and training can be helpful in such an assessment. 


\section{A. Institutional Arrangements as They Relate to Key Elements}

\section{Policy Coordinating Body, Support Committees and Control of Level of Indebtedness and its Composition}

1.How could the government's decision-making process for contracting new public foreign currency debt be described? (Please mark as appropriate)

------(i) The central government raises all external funding required by the public sector and passes /on lends the funds to public sector agencies.

-----(ii) The central government raises central government funding needs only and public sector agencies raise their own funding with central government guarantee.

------(iii) The central government raises central government funding needs only and public sector agencies raise their own funding without central government guarantee -----(iv) Other arrangements. Please explain-

2.If the answer to the previous question was (i) or (ii), which institution bears the foreign exchange risk in borrowing transactions whose proceeds will go to public sector agencies?

The central government

The public sector agency

Other (explain)

3.Please indicate which of the following is the highest government authority whose approval is required for all new borrowings?

------Parliament approves through legislation

------An inter-ministerial board or equivalent (High Level Debt Policy Body)

-------The Minister of Finance, Central Bank Governor or equivalent

------Other, Please specify-

4.Is this authority responsible for establishing borrowing policy and limits for debt indicators to guide the level of indebtedness? ----Yes ---No

5.Specify the composition of the body/committee which develops borrowing policy. 
6.Describe the current official borrowing policies?

7.Are projects, which receive foreign finance, listed in a medium-term Public Investment Plan(PIP) ? Or are central government borrowings undertaken for projects randomly by different Ministries without reference to a medium-term plan?

8. Does the Planning Ministry undertake appraisal for all projects enlisted in the PIP? ----Yes ------No

9. Which agencies have responsibilities for undertaking medium-term balance of payments projections and forecasting the fiscal budget? Please List-

10. Do these agencies work closely with the Debt Unit ------Yes ----No

Comment

11.How are these exercises coordinated? (Check as appropriate)

------A committee comprising Central Bank, Ministry of Finance and debt management officials is established for articulating export performance, imports requirements, economic growth prospects in relation to the debt profile in mediumterm balance of payments and fiscal projections.

-----The Central Bank or Ministry of Finance unilaterally forms perceptions on these projections.

------largely through international financial institution's assistance e.g. IMF and World Bank

---.---Other (specify)

12.Apart from making projections to articulate new borrowings, is there a mechanism in place to discuss the cash-flow constraints (foreign and local), which debt service payments may have on other sectors of the economy? ----Yes --.--No Please comment- 


\section{The Debt Unit, Debt Monitoring and Debt Data Analysis}

1.Where is the Debt Unit located?(mark as appropriate)

------Ministry of Finance

------Central Bank

-------An autonomous body

2.Which categories of debts are monitored by this Unit? (Mark as appropriate)

Government direct debt

Government guaranteed debt

Public enterprise direct Debt

Private non-guaranteed debt

3.Is detailed information on all categories of debt centralized in the Debt Unit, or do different agencies handle details of different categories of debt? Specify agencies accordingly

Government direct debt-

Government guaranteed debt

Public Enterprise Direct Debt

Private non-guaranteed debt-

4.Does the Debt Unit keep inventory of all loan agreements on government and government guaranteed borrowings? -----Yes -----No

5.How are loan agreements made available to the Debt Unit? (Mark as appropriate)

----Debt Unit evaluates loan proposals, keeps track of loan negotiations and requests loan agreements from Ministry of Finance after signature

----- No prior evaluations are undertaken. Debt Unit becomes aware of debt only after signature and has to go in search of signed loan agreements after negotiations

------Ministry of Finance authorities readily provide copies of loan agreements to Debt Unit after signature

6.Does the Debt Unit get statements for all transactions on disbursements directly from creditors or locally from project implementing agencies?

7.How frequent are delays encountered with the commencement of disbursements after signing loan commitments?
$\square$ Very often
$\square$ quite often
$\square_{\text {occasionally }}$
$\square_{\text {never }}$ 
8. Which agencies of government have responsibility for processing disbursement applications to creditors for government and government guaranteed debt? Mark as appropriate

Project implementing agencies-

Ministry of Finance-

Government General Account Department

Other (specify)

9.How accurate are forecasts of annual debt servicing obligations provide by the Debt Unit for annual budgetary and foreign reserve management?

10.Which agencies are involved in effecting debt service payments on Government direct debt and Government guaranteed debt -Central Bank, Treasury, Debt Unit? Please indicate---

11.Are difficulties encountered with cooperation among agencies, which cause delays in effecting debt service payments? -----Yes -----No Comment-

12. Which stage of the debt service process is typical the source of delay?

----Debt Unit does not provide instructions on due payments in time -----The Accountant General's Department delays in posting payment instructions to the Central Bank/External Finance Department

----Central Bank/External Finance delays in remitting funds to creditors

-----Other (explain)

13. How frequent are penalty charges for late payments? ------Yes -----No

$\square$ Very often $\quad \square$ quite often $\quad \square$ occasionally $\quad \square_{\text {never }}$

14.How large are penalty charges as percent of monthly debt service payments?

15.If the Central Bank has complete information on debt service due, has it got blanket authority to effect payments and later reconcile accounts with government?

16.Is there a Working Group or Committee set up to facilitate flow of information and debt monitoring processes among the various agencies in debt management operations?--Yes --No

17. What is its composition and activities? 
18. Are new borrowing proposals evaluated to analyze the effects of the currency composition, interest rate structure and maturity profile on the overall loan portfolio? -.--Yes -----No

\section{B. Computer Tools for and Training in Debt Monitoring and Debt Analysis}

\section{Computer tools}

1. Which of the following computer-based external debt systems is currently used by your government for creating detailed loan-by-loan database?( Mark as appropriate)

-----CS-DRMS

-----UNCTAD- DMFAS

-----Country's own system

--------Other - specify-

2. What types of debt reports are produced on monthly, quarterly and yearly basis for the use of debt policy makers? -------Please list these reports----

3.Does the system readily produce reports that meet country specific needs such as:

Debt Service due on monthly, quarterly and yearly basis

Actual Debt Service on monthly, quarterly and yearly basis

Disbursements (actual and forecast)

Others (specify)

4.Is the debt software effective in assisting with -

debt rescheduling exercises?

evaluating effects of new borrowings?

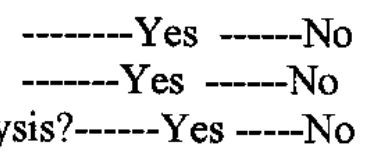

5.Is there need for a special software package to complement the existing debt software to undertake debt strategy analyses (e.g. Debt-Pro or World Bank-DSM+)? Yes--------

No-------

6. Does the country use Debt Pro, DSM+ or other software for DSA? Comment

\section{Training}

6.Has staff in the Debt Office acquired basic training in the interpretation of loan agreements, use of software for recording and updating loan transactions, providing projections on debt service and disbursements? 
7.How equipped is local staff capacity in undertaking debt analysis in the following: Paris Club rescheduling simulations? Evaluating new borrowing proposals? Conducting DSAs?

8.Is there need for further advanced training? --------Yes ------No Specify areas for further training

9.Are the Commonwealth Secretariat and UNCTAD, as the case may be, providing regular training support in the above areas? -----Yes $--\cdots-$ No Comment-----------

10.Has the Debt Relief International been contacted to assist in building capacity in undertaking debt strategy analysis? -----Yes -----No Comment on assistance requested------- 


\section{Project Cycle for Setting up a Computer-Based Debt Management System}

Whatever type of computer-based debt management system a country adopts, its development must follow some specific stages. These include:

Initial assessment: Expert advisor on debt management assesses the existing institutional arrangements for debt management, including procedures for contracting and monitoring debt to identify the user needs. This forms the basis for modifying the existing institutional arrangements to make installation of a system feasible.

Institutional arrangements: The government takes action to establish appropriate institutional arrangements and procedures to facilitate information flow to the system and other policy analysis. A project coordinator is appointed to direct the installation of the system. (Expatriate or otherwise)

Debt inventory: Information on existing debt is coded on data entry sheets used by the system. Staff is trained on how to interpret loan data and how to code the information. Cut-off date for historical data is established.

Training key staff: Staff in the Debt Unit is trained in the use of the debt software on data entry, update of transactions, generating reports.

Installation: The system is installed in the Debt Unit. Prior to this, computers and other peripheral equipments have been purchased. Installation also involves training remaining staff on the system. The institutional arrangement may need to be reviewed at this stage. To ensure the flow of information.

Applications: Staff get further training in carry out forward looking analysis and writing reports that suit country specific needs. At this stage debt management staff are readily prepared to use the system in monitoring and managing external debt. 


\section{Bibliography}

Avramovic, Dragoslav, 1964, Economic Growth and External Debt (Baltimore: Johns Hopkins Press).

Andrews, David, Anthony R. Boote, Syed S. Rizavi, and Sukhwinder Singh, 1999, Debt Relief for Low-Income Countries-The Enhanced HIPC Initiative, IMF Pamphlet Series No. 51 (Washington: International Monetary Fund).

Boote, Anthony R., and others, 1998, Official Financing for Developing Countries, World Economic and Financial Surveys (Washington: International Monetary Fund).

Brooks, Raymond, and others, 1998, "External Debt Histories of Ten Low-Income Developing Countries: Lessons from Their Experience," IMF Working Paper 98/72 (Washington: International Monetary Fund).

Chenery, H.B. and Strout, A.M., 1966, "Foreign Assistance and Economic Development," American Economic Review No. 56 (September), pp. 680-90.

Daseking, Christina, and Robert Powell, 1999, "From Toronto Terms to the HIPC Initiative; A Brief History of Debt Relief for Low-Income Countries," IMF Working Paper 99/142 (Washington: International Monetary Fund).

Draft Guidelines for Public Debt Management, August 2000 (unpublished; Washington: International Monetary Fund and World Bank).

Gutowski, A., Holthus, M., and Kebschull, D., 1986, Indebtedness and Economic Growth in Developing Countries (Hamburg: HWWA).

HIPC Guide Book, January 1999 (unpublished; Washington: International Monetary Fund).

Kitabire, Damoni, 1997, "Uganda's Debt Strategy: An Example of the Need for Flexible, Coordinated Institution in a Changing Macroeconomic Environment" (unpublished; Kampala).

Kalderen, Lars, 1992, "Institutional aspects of external debt management" in Managing External Debt in developing Countries: Proceedings of a Joint Seminar, Jeddah ed. by Thomas M. Klein, pp. 87-97.

Klein, Thomas M., 1994, "External Debt Management: An Introduction" World Bank Technical Paper No. 245 (Washington: World Bank). 
Senhadji, Abdelhak, 1997, "Sources of Debt Accumulation in a Small Open Economy," IMF Working Paper 97/146 (Washington: International Monetary Fund).

UNDP, 1997, “Debt Management" Discussion Paper 4 in A report on The Joint Programme of Debt Management 1991-1996; November. 